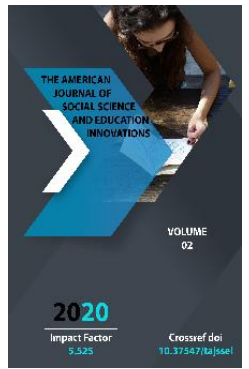

Journal Website: http://usajournalshub.c om/index,php/tajssei

Copyright: Original content from this work may be used under the terms of the creative commons attributes 4.0 licence.

\section{The Importance Of Listening In Foreign Language Learning}

\author{
Karimova Jamila Shariyevna \\ Tashkent Institute Of Irrigation And Agricultural Mechanization Engineers, Tashkent, \\ Uzbekistan
}

Israilova Dildora Atxamovna

Tashkent Institute Of Irrigation And Agricultural Mechanization Engineers, Tashkent, Uzbekistan

\title{
ABSTRACT
}

This article is devoted to the role of listening skill and it's different types in terms of obtaining new language. The stages which are typically used in order to do listening are given with their instructions in the article.

\section{KEYWORDS}

Listening skills, competent listener, extensive and intensive listening, concentration.

\section{INTRODUCTION}

Listening, as we know, is the skill of understanding spoken language. Listening is an essential skill, present in most activities we carry out throughout our lives. We listen to a variety of things, for example, a lecture; a play on the radio; the weather forecast on the radio; a taped dialogue in class. It has taken many years to give the listening skill the importance it deserves in second and foreign language learning among the teaching profession. 
Listening was one of the most neglected skills in second and foreign language classrooms especially until late 1960s. both researchers and language teachers paid more attention to reading, grammar, and teaching listening was not accepted as a significant feature of language teaching. Field states that" in early days of English Language Teaching(ELT), listening served as a means of introducing new grammar through model dialogues" $[1 ; 89]$ Recently, the language teaching profession has brought into focus on listening comprehension.

Listening skills have been studied by many researchers. Listening has an important role both in daily life and in academic contexts as it is crucial for people to sustain affective communication. Of all the four main language skills, listening is the most influenced one. In 1970s, listening with more importance it has gained as skill, started to take place in language teaching programs besides speaking, reading and writing. Listening plays an important role in communication in people's daily lives. As Gou and Wills state "it is the medium through which people gain a large proportion of their education, their information, their understanding of the world and human affairs, their ideas, sense of values".

As for Peterson, he states that" no other type of language input is easy to process as spoken language, received through listening , learners can create an awareness of the inter workings of language systems at various levels and thus establish a base for more fluent productive skills". Most people think being able to write and speak in a second language means that they know the language, however, we think that if they do not have the efficient listening skills, it is not possible to communicate effectively. That is, listening is the basic skill in language learning as we prove it above with clear statements. The aim of teaching listeningis to help learner of English cope with listening in real life, but there is a large variety of different types of listening in real life:

- Listening to the announcements in stations,airports

- Listening to the radio

- Participating in a meeting, seminar or discussion

Different situations require different types of listening. In the classroom situation, students can improve their listening abilities and gain valuable input by being engaged in the listening process through a combination of extensive and intensive listening.

\section{MATERIALS AND METHODS}

Most researchers like to make the difference between "extensive and intensive" listening .The two types are described by Harmer (1998) to have a special importance. They provide students with the perfect opportunity to listen to other speakers than their teacher's.

"They help them to develop their pronunciation and acquire good speaking habits they absorb"

Extensive listening

It occurs in a situation where the teacher encourages students to choose for themselves what they listen to, using their own materials for the purpose of pleasure and language improvement . 
Extensive listening materials differ, they can be found from different resources such as recordings of stories, passages taken from books, television, radio.... All the mentioned sources tend to treat spontaneous conversations, dialogues, interviews... etc. According to, foreign language teachers can enrich their classes with effective input carrying out extensive listening through a well chosen and appropriate tapes in different levels, genres and topics. Creative teachers can recommend certain tapes and ask students to talk about the ones they have enjoyed the most.

Intensive listening

The other type of listening is the intensive one. It is practiced in every day situations the, ability to listen intensively is considered to be an essential part of listening proficiency. It refers to" the process of listening for precise sounds words, phrases, grammatical units and pragmatic units". As far as intensive listening is concerned, it invites the learners to meet different characters specially when real people are talking in real life situations, interact with speakers, interrupt them and why not asking for clarification this is what is named " live listening".

"Live listening" is among the good ways to carry out intensive listening. It can take many forms; such as the teacher's reading aloud to a classroom. Students dealing with this task listen to a natural spoken language of a written passage. In addition to other enjoyable activities like storytelling, conversations and interviews. [2;96]

Consequently, intensive and extensive listening are two important ways to ensure the realization of listening in general and they have to be used appropriately.

As the types of listeners, competent listener who is considered tohave a high listening ability and one of the most essential type of listeners .The listener in this category is capable of:

- Understanding all the types of speech, concerning those easy to be understood by native listeners in the target community or the abstract.

- In case speech is unintelligible, the listener can seek clarification easily, he is able to depict whether his knowledge in a certain communication situations is enough to teach an acceptable level of understanding or not, as well as being able to note where the speaker is ambiguous and vague.

- It is noted that competent listener is elected to perform well concerning any task demanding oral comprehension

\section{RESULT AND DISCUSSION}

People experience several stages whenever they are practicing it. They are required to be awarz of about them beforehand in order to grasp the meaning. 
Pre-listening

Pre-teach vocabulary in order to ensure maximum understanding

Listening

Extensive listening followed by general questions on context Intensive listening followed by detailed comprehension questions

Post-listening

Teach any new vocabulary, analyze language

As the figure illustrates, there are three parts in a usual listening lesson: prelistening,(while)listening and post -listening 1) Pre-listening would be the first stage, where the context is established. The teacher creates motivation and students do some activities with the purpose of preparing them for what they will hear.

2) The following stage is listening, where learners do the mentioned tasks or find answers. There are two kinds of material and procedure. On the one hand, extensive reading helps students to acquire vocabulary and grammar and it usually takes place outside the classroom.

3) The last stage is post-listening, the part where students have the opportunity to check their answers about they have been listening to, to give feedback and consolidate what they have learnt. It is useful for teachers because it helps to analyze particular difficulties the students could have with the listening activity. In addition to this, this part gives a chance for students to state their opinions in terms of particular topic.

\section{CONCLUSION}

Listening skill has an important role both in daily life and in academic contexts as it is crucial for people to sustain effective communication. Listening skills are important for learning purposes since through listening students receive information and gain insights. Also, listening is vital in the language classroom because it provides input for the learner. That is, in learning language, the 50\% of the time that students spend functioning in a foreign language will be devoted to listening.

\section{REFERENCES}

1. Field J. skills and strategies: Towards a new methodology for listening". ELT Journal(1998)

2. Field $J$."listening in the language classroom". United Kingdom: Cambridge University Press.

3. Rost .M "Listening in language learning". New York .London. (1990)

4. Rost , M. "Introducing listening" . London.(1994). 